\title{
In recognition of Ireland's medical scientists-Arnold Hill, Mark Lawler, Ian Young and Kingston Mills
}

\author{
W. P. Tormey ${ }^{1,2,3,4}$
}

Published online: 3 August 2017

(C) Royal Academy of Medicine in Ireland 2017

Recognition of excellence in public and professional service by the state is a feature of many European countries. Herein follows some examples. In the UK, the honours system includes titles resonating of monarchy and empire, commander, officer and member $(C B E, O B E, M B E)$ of the British Empire. In France, the Ordre national de la Légion d'honneur was established in 1802 by Napoléon Bonaparte. In Germany, the 1951 Verdienstorden der Bundesrepublik Deutschland is the only federal decoration. In the Netherlands, De Orde van de Nederlandse Leeuw for outstanding contribution was founded in 1815 by King William the 1 st.

In the Republic of Ireland, public honours are not awarded by the government. The Royal Irish Academy and third level educational colleges fulfil the role independently. In Northern Ireland, honours are awarded through the UK government and the universities also award honourary degrees to outstanding people.

The Irish Journal of Medical Science will publish a series on people in medicine and health sciences who are clearly worthy of public recognition. The Editor in Chief is the sole selector. The individuals featured will be graduates of Irish universities or have worked in Ireland for a prolonged period.

W. P. Tormey

billtormey@gmail.com

1 Department of Chemical Pathology, Beaumont Hospital, Dublin, Ireland

2 Biomedical Sciences, Ulster University, Coleraine, UK

3 Medical School, Trinity College Dublin, Dublin, Ireland

4 Health Sciences, Athlone Institute of Technology, Westmeath, Ireland

\section{Honours list for summer 2017}

\section{Professor ADK Hill}

Arnold Hill is Professor of Surgery and Head of the Medical School at the Royal College of Surgeons in Ireland. He graduated from University College Dublin Medical School in 1988; he trained at the University of Pennsylvania, the New York Hospital and Sloan Kettering Cancer Centre in New York and the Central Middlesex hospital in London, England. His laboratory research interests are in the transcriptional control of breast cancer and in particular the role of the coregulatory proteins and he has 300 publications in the medical literature. $(1,2)$. Professor Hill's H index on Google Scholar is 44.

\section{References}

1. Hill AD, Tran KN, Akhurst T et al. 1999. Lessons learned from 500 cases of lymphatic mapping of breast cancer. Ann Surg 229:528-35.

2. Duffy MJ, Maguire TM, Hill AD, et al. 2000 Metalloproteinases: role in breast carcinogenesis, invasion and metastasis. Breast Cancer Res 2;252-7.

\section{Professor Mark Lawler}

Dean of Education in the School of Medicine, Dentistry and Biomedical Sciences and professor at the Centre for Cancer Research and Cell Biology at Queens University Belfast.

In 1985, Professor Lawler graduated from the Genetics Department, Trinity College, Dublin. He played a key role in the development of molecular genetics at TCD and at St James Hospital, Dublin 8, where he was appointed Associate Professor in Experimental Haematology/ Oncology and Honorary Associate Professor in Oncogenetics, Smurfit 
Institute of Genetics, TCD. He is Visiting Professor in Medical Genetics and Molecular Medicine, University of Chieti, Pescara, Italy, for 12 years. From 2013, he is Professor of Translational Cancer Genomics at Queens University Belfast.

His main interests are in cell cycle control and its manipulation in haematological malignancy.

In 1991, he earned a PhD from Trinity College, Dublin, and was awarded the Vander Molen Prize for Leukaemia Research at the British Society of Haematology. In 1996, he was invited to deliver the 22nd Annual St Luke's Medal Lecture at the Royal Academy of Medicine in Ireland, 1996.

In 2001, he delivered the 7th Annual Ulster Cancer Foundation Award Lecture and in 2004 the 44th Annual Graves Medal Lecture at the Royal Academy of Medicine in Ireland. In 2006, he was awarded FRCPath on the basis of published work Royal College of Pathologists, London.

On ResearchGate, he is listed with 266 research items and 4234 citations.

References

1. Alderdice M, Dunne PD, Cole AJ, et al. (2017) Natural killer-like signature observed post therapy in locally advanced rectal cancer is a determinant of pathological response and improved survival. Modern Pathology doi:10. 1038/modpathol.2017.47

2. Dunne PD et al.(2017) Cancer-cell intrinsic gene expression signatures overcome intratumoural heterogeneity bias in colorectal cancer patient classification. Nat. Commun. 8, 15,657 doi: 10.1038/ncomms 15657.

\section{Professor Ian Young}

Professor Young is Clinical Professor at the School of Medicine, Dentistry and Biomedical Sciences and Centre for Public Health and Institute for Global Food Security at Queens University Belfast. He is Associate Medical Director for Research and Development and Consultant in Chemical Pathology at the Royal Victoria Hospitals in Belfast.

In 1982, he graduated from Queens University with BSc in Biochemistry and in 1985 with the MB, BCh, BAO degree. He earned an MD in 1994 and was awarded FRCP (London) in 1998 and FRCPath in 2001. He is the winner of many research awards including the Professors' prize at the Association of Clinical Biochemists and the foundation award for an outstanding contribution to Clinical Biochemistry.

Lipidology and cardiovascular health are outstanding issues in his life's professional work. His total research grant funding income is greater than $£ 15$ million. His pathway to excellence was set out at Sullivan High School. He became an outstanding contributor to thesis examinations and evaluations for many universities. He is an editorial board member of many journals in clinical chemistry worldwide.
On ResearchGate, he has 560 research items listed and 13,225 citations.

References

1. The Diabetes Pre-eclampsia Intervention Trial (DAPIT) Study Group (2017). Effects of pregnancy planning on maternal and neonatal outcomes in women with type 1 diabetes. Diabetic Medicine. DOI: 10.1111/dme.13398

2. McKay GJ, Young IS, McGinty A, et al. Associations between Serum Vitamin D and Genetic Variants in Vitamin D Pathways and Age-Related Macular Degeneration in the European Eye Study. Ophthalmology. 2017 Jan;124(1):90-96. doi: 10.1016/j.ophtha.2016.09.007. Epub 2016 Oct 28.

\section{Professor Kingston Mills}

Professor Mills is Professor of Experimental Immunology, School of Biochemistry and Immunology, Trinity College, Dublin (TCD). He is head of the Centre for the Study of Immunology at Trinity Biomedical Sciences Institute and Theme Champion for Immunology, Inflammation and Infection at TCD.

He schooled at Wilson's Hospital. He is a graduate of TCD in 1972 and earned a PhD in 1980. He trained as a Postdoctoral Fellow at University College London and the National Institute for Medical Research, Mill Hill, London, before joining the Scientific Staff of NIBSC, Herts, UK.

In 1993, he was appointed to NUI Maynooth in Immunology.

In 1999, he delivered the 39th Graves Lecture at the Royal Academy of Medicine in Ireland.

In 2001, he was appointed to a personal chair in TCD and was Head of the School of Biochemistry and Immunology from 2008 to 2011.

In 2004, he received the Royal Irish Academy award in Biochemistry.

He is a Co-founder, Chief Scientific Officer of the spin-off campus company, TriMod Therapeutics Ltd., involved in the development immunotherapeutics and vaccine to treat cancer.

He has 283 peer reviewed publications. In June 2016, Kingston Mills was ranked number 17 in the Republic of Ireland in the Google Scholar listings with an H-Index of 74 and citations of 17,993 . He was also a good athlete as a student for TCD!

References

1. Varghese S, Cotter M, Chevot F, et al. 2017. In vivo modification of tRNA with an artificial nucleobase leads to full disease remission in an animal model of multiple sclerosis., Nucleic Acids Research, 45, 2029-2039. https://doi. org/10.1093/nar/gkw847 
2. Misiak A, Wilk MM, Raverdeau M, Mills KHG. (2017) IL-17-producing innate and pathogen-specific tissue resident memory Î3î̌̌ T cells expand in the lungs of Bordetella pertussis-infected mice, Journal of Immunology, 198, (1), p363-374. https://doi.org/10.4049/jimmunol.1601024 